\title{
Wooden heritage of Świętego Piątka St. in Zamość. Problems and ideas for the preservation of a vanishing landscape
}

\author{
Katarzyna Kielin \\ https://orcid.org/0000-0001-5370-5686 \\ k.kielin@pollub.pl \\ Department of Architecture and Urban Planning, Faculty of Civil Engineering \\ and Architecture, Lublin University of Technology
}

\begin{abstract}
Wooden heritage of Polish towns has become a widely discussed architectural topic. Until the $2^{\text {nd }}$ world war, the majority of little towns and villages development was constructed from wood. Zamość, well-known for its inclusion in the UNESCO World Heritage List, may be pleased for having many examples of wooden residential architecture dating back to the beginnings of the $20^{\text {th }}$ century. Stylistic traits, composition of forms, modest but classy ornamentation and the atmosphere of the street calls for adequate commemoration. Private ownership entailing infrequent poor maintenance, devastating weather conditions, lack of concrete, local government actions result in gradual deterioration of wooden building substance and its aesthetic, original qualities. Too little attention and effort is devoted by the local government to preserve that unique part of Zamość - the Zamość outside the fortification walls.

The author of the article provides historical background of that particular pieces of wooden architecture, lists their main characteristics distinguishing and common to the Zamość region, discusses their role in the street's landscape and presents several solutions to revive the original beauty of the place and engage attention to the matter.
\end{abstract}

Keywords: wooden architecture, Zamość, Świętego Piątka Street, preservation, public space

\section{Historical overview of the Świętego Piątka area}

Świętego Piątka Street constituted one of the three parts of the so-called Lviv Trail which dates back to the end of $16^{\text {th }}$ century. After the Lviv trail had changed its course at the beginning of the $19^{\text {th }}$ century the previous route of that trail, was started to be called 'Old Road' or the 'Old Lvovian Track' and was later divided into three streets: Krysińskiego, Żdanowska and Świętego Piątka. Dominant types of dwellings are wooden, single-family housing estates which come from the beginning of the $20^{\text {th }}$ century (many of them dating back to the 1920' and 1930'). The street was named in around 1927 but, for almost 40 years, it was known as '22lipca' St. (1951-1990). The street was a part of the historical Lvovian Suburb. A characteristic element of the street is a statue whose symbolism was attributed to various stories, legends. The street stretches for about seven meters. In the middle twenties in $19^{\text {th }}$ century, Nowa Osada (New Settlement) was the second largest area (after the Old Town, 6168) with a total of 4682 inhabitants. ${ }^{1}$ The street closed the area of the Nowa Osada settlement. The map, from the beginning of the $20^{\text {th }}$ century shows the location of the street with the arrangement of the New Market Square ${ }^{2}$. 


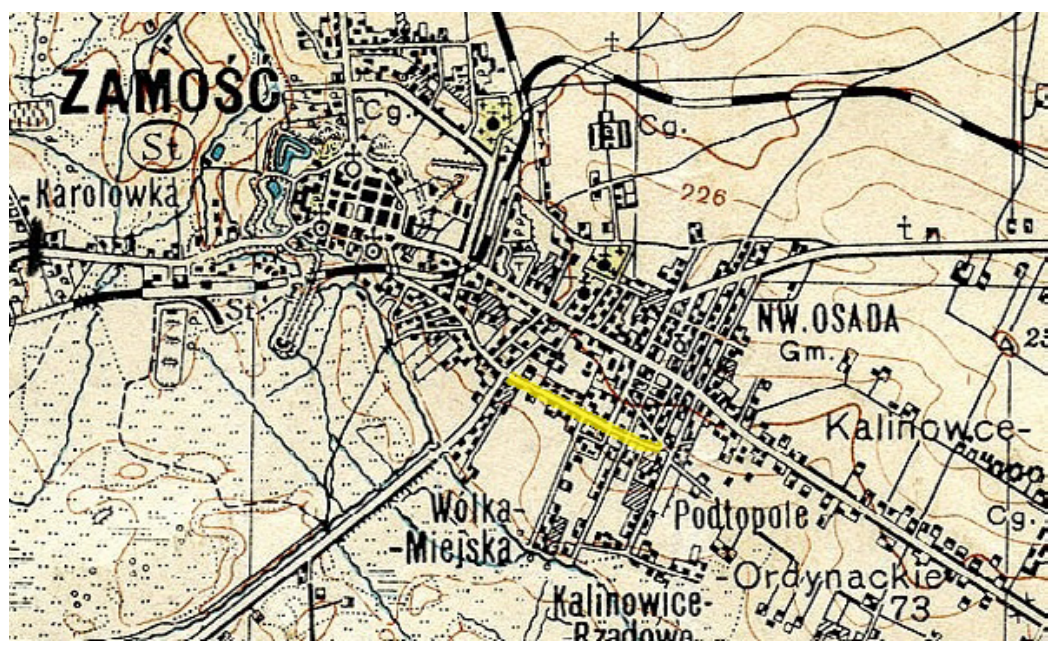

Fig. 1. The location of Świętego Piątka St. Zamość i okolice 1936 - Mapa topograficzna, pas 46 - słup 36. Zbiór kartograficzny

Source: Courtest of the Zamość Archives, online archives: Kartografia - Zamość i okolice - 1936 r.

Teka Zamojska from 1920 was a local academic publication which popularized the Zamość historical heritage as a town of various architectural and urban, artistic values, as well as some insights into the lives of famous people somehow connected with Zamość. It was issued by the Pomarański Bookstore It includes a series of articles published in consecutive editions which describe characteristic features of little town and village wooden houses of the Zamość region (Moszyński Kazimierz, "Budownictwo ludowe w okolicy Zamościa"). Shapes of roofs, wooden cladding, the organization of the main entrance, porches, verandas, dormers, ornamentation and chimney materials. ${ }^{3}$ Typically, little town wooden residential buildings were oriented with their longer wall, ridge-oriented towards the street. The main entrance to the building is positioned in the middle of a longer wall. Another characteristic feature stated in that article is frequently occurring hipped-gable rooftop with a protruding dormer topped on a built-up porch. Some houses were two-family dwellings, therefore, both parts of the house were put together (Fig. 2).

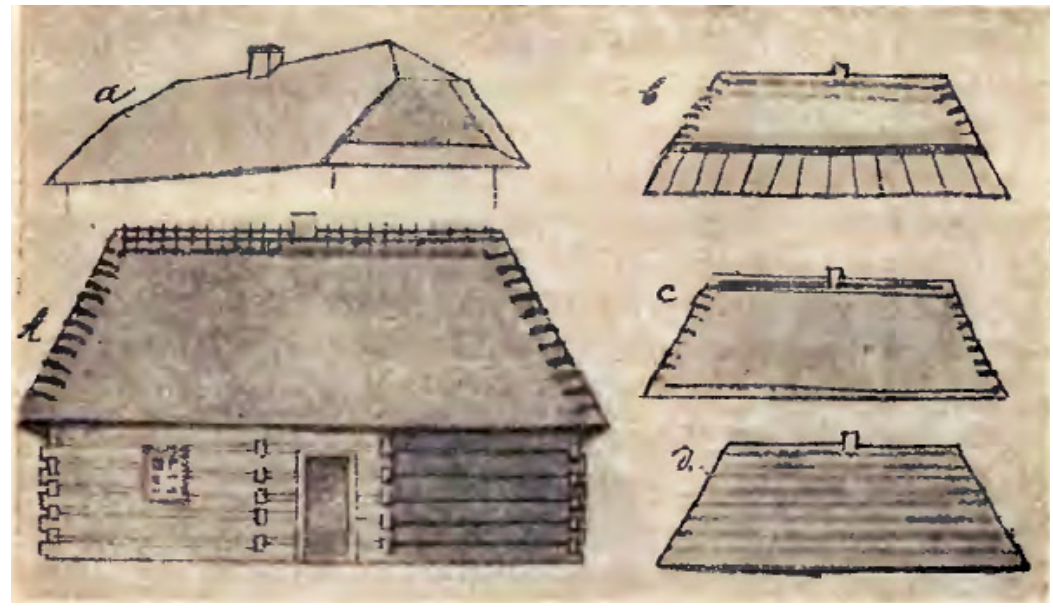

Fig. 2. A typical village house from Wielącza; Rooftops of village houses on the outskirts of Zamość, author: K. Moszyński, Teka Zamojska. Rok III. Nr 2 (Luty 1920, p. 29) 


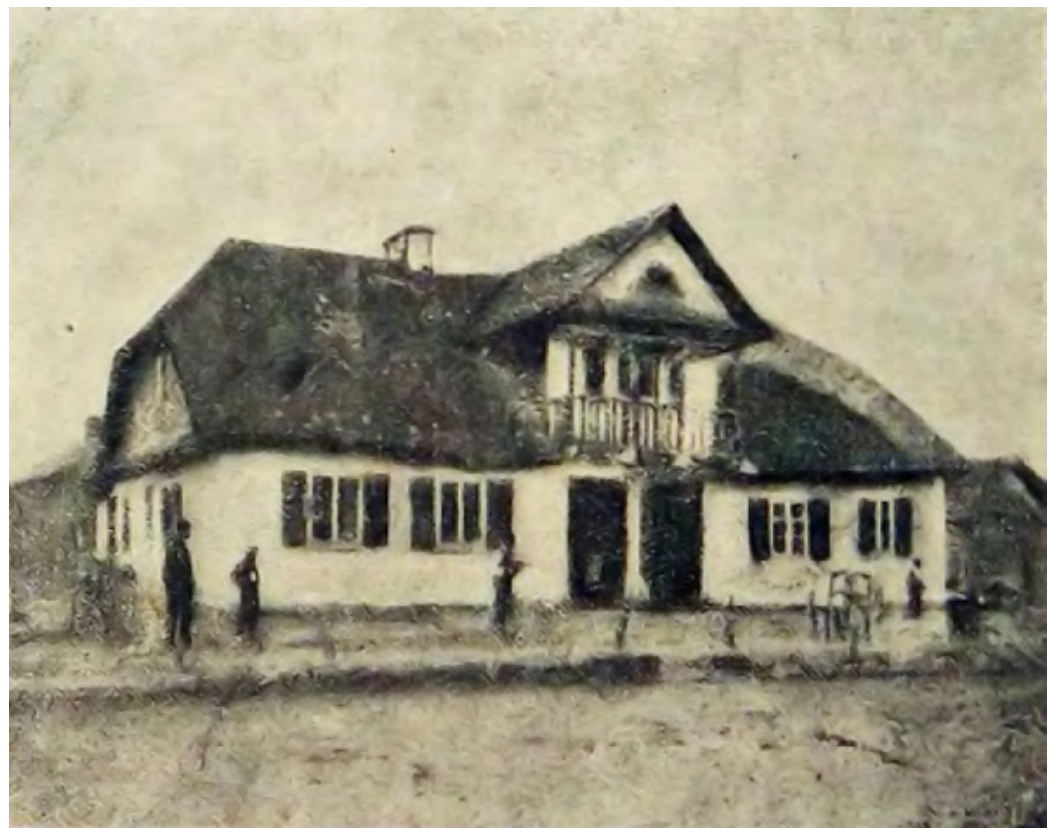

Fig. 3. A house in Nowa Osada, author: Wł. Krzaczyński, Teka Zamojska. Rok III. Nr 3 (Marzec 1920, p. 45)

\section{Świętego Piątka 1}

The residential single-family building has got a form of a rectangle in its layout, with a protruding entrance part in the shape of a porch which extends vertically to the attic area. Frontal side of the building is characterized by symmetrical division of architectural elements. The porch is situated right in the middle, main axis; the main volume of the building is articulated with that porch. Triangular frontage is finished with radially formed wooden planks. The edges of a triangular frontage are finished with wooden artwork - woodcarvings with the peak marked with three wooden arrows. Outer wooden finishing is arranged both vertically and horizontally and marks the area of both ground lower part and the window zone until the line of the roof overhand. The finishing accentuates structural division of the building and serves as classy and not obtrusive stylistic/ architectural detail. Simplicity and clarity of form are combined with scarce details. Unfortunately, a fairly common practice of insulating such buildings devastates their original, traditional beauty which comes from the wooden finishing; the aesthetics of the building is substantially distorted. The house has got white-framed casement windows with two panes divided into six squared segments each. Window frames of the porch area are thinner than the ones located in the main part of the building. Both gable walls follow middle line of symmetry and are covered with green wooden planks arranged vertically and horizontally in geometrical layout. The proportions of the whole are balanced and.

One of the most valuable examples of villa - like wooden buildings (Świętego Piątka 1) - dating back to 1935 is now hidden behind totally unimpressive, context-neutral, dull, unremarkable, unmemorable plastered, insulation material(?!) taking into account the fact that the building is on the list of recorded monuments, safeguarded by the rules included in the Zamość zoning plan. 


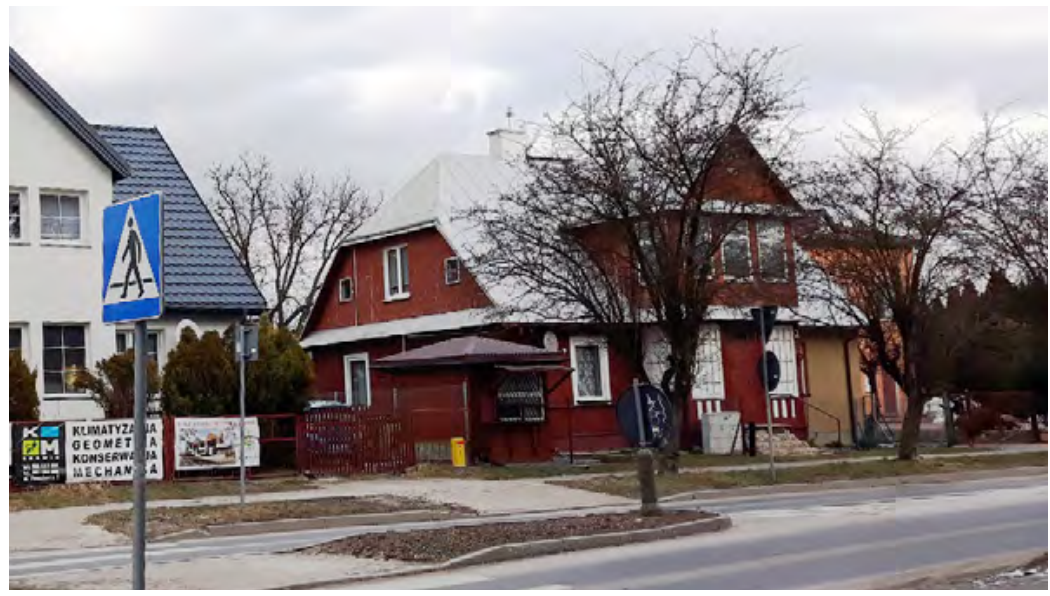

Fig. 4. Wooden residential building, Świętego Piątka 1, its original character has been tarnished by decontextualizing finishing with insulation and plaster covering; moreover, it has been hidden behind a great number of billboards and outdoor advertisements; a roundabout area between Świętego Piątka St. and Lipsa St.

Source: author's photograph

\section{Świętego Piątka 3}

The building is situated at the opening of Świętego Piątka St. The building is characterized by a hipped-gable roof, wooden finishing of the wall patterned primarily in horizontal planks from the lower window line right up to the overhang. Bottom part, between the windows and a concrete band, is clad with vertically aligned brown wooden planks. Similarly to the Świętego Piątka 1, the main frontal axis is accentuated with a protruding two-storey porch structure with a radially arranged area of a tympanum. The porch has got two lines of white-framed wooden windows, three in each line. The entrance is positioned symmetrically and elevated for five steps. The building comes from 1933 and the date is placed in the middle of the tympanum. Lower line of windows installed in the porch has a different division into segments (sixteen segments per each window). At the moment, the building is partially insulated which distorts its symmetry.

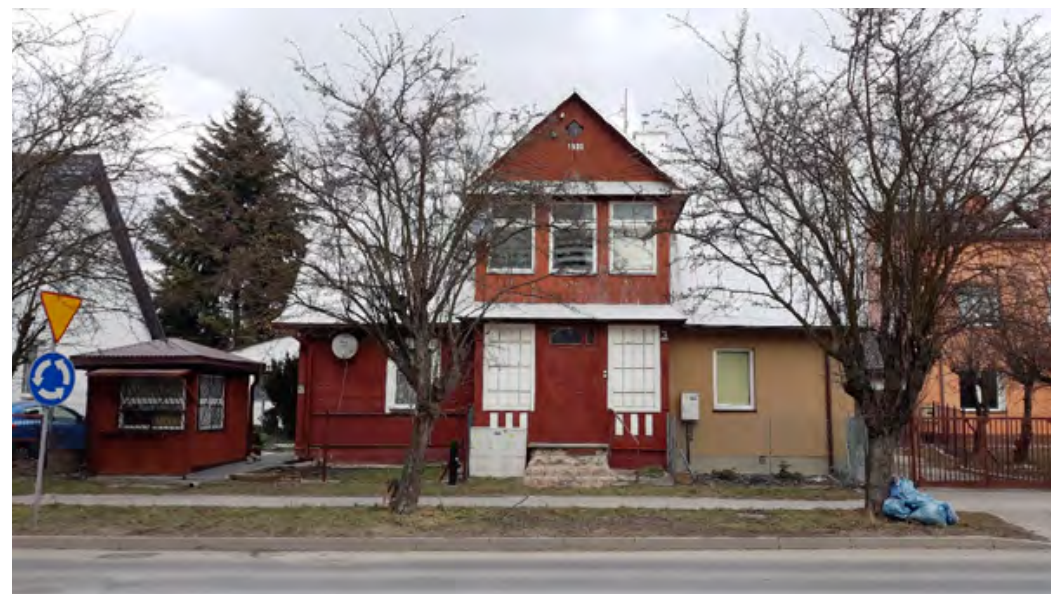

Fig. 5. Wooden residential building, Świętego Piątka 3

Source: author's photograph

\section{Świętego Piątka 4}

The residential building has a ground floor plan with the inhabited attic area. As far as the elevation layout is concerned, it follows the pattern visible on previous buildings. The form is symmetrical, accentuated with a built-up porch in which there are two thin windows, a door and a glass half-rosetted, sun-like tympanum. A line of four double-planed windows each equipped with a fanlight. The building is topped with a hipped-gable roof. There is a concrete wall base which outlines both the main part together with the porch area. 


\section{Świętego Piątka 7}

The Świętego Piątka 7 wooden house has got a simpler form than the previous ones and many characteristic features similar to the ones described earlier. The ground floor building with a hipped-gable roof, with a line of one-paned, white-framed windows placed symmetrically on both sides is painted in grey. There is a possibility that the window frames might be made of plastic which is another violation of the house's original appearance. The proportions of the building are steady and harmonious. The building is topped with a brick chimney placed centrally above the entrance.

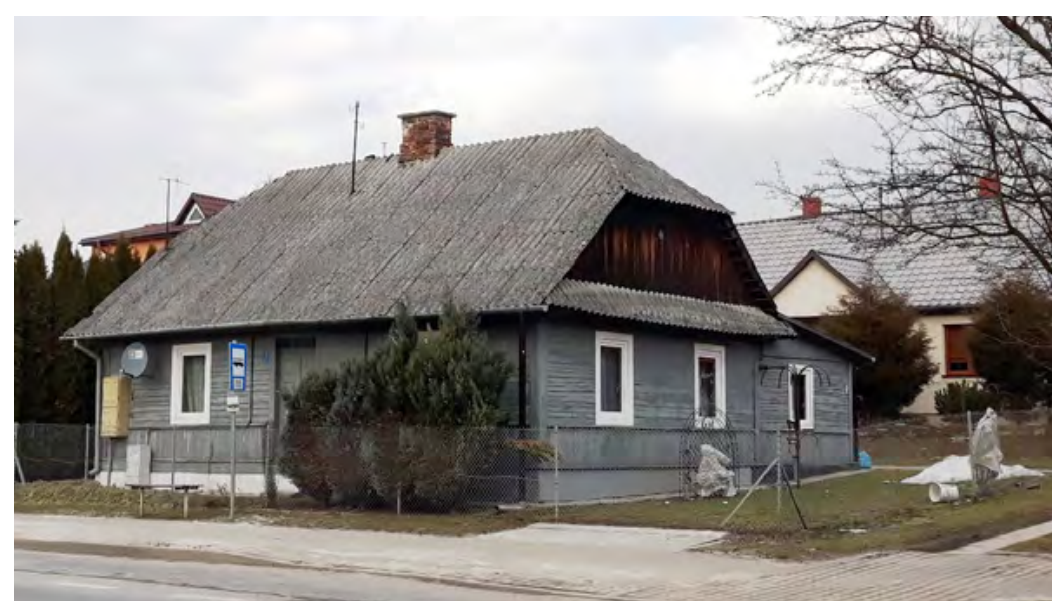

Fig. 6. Wooden residential building, Świętego Piątka 7

Source: author's photo

\section{Świętego Piątka 14}

The building under the following address differs from the other examples quite substantially in terms of its proportions and the location of a porch which is characterized by numerous divisions of segments of three window panes. It comes from the 1920' and it used to belong to the family of Stopa. Its narrow frontal side has got two white-framed windows, facing the street.

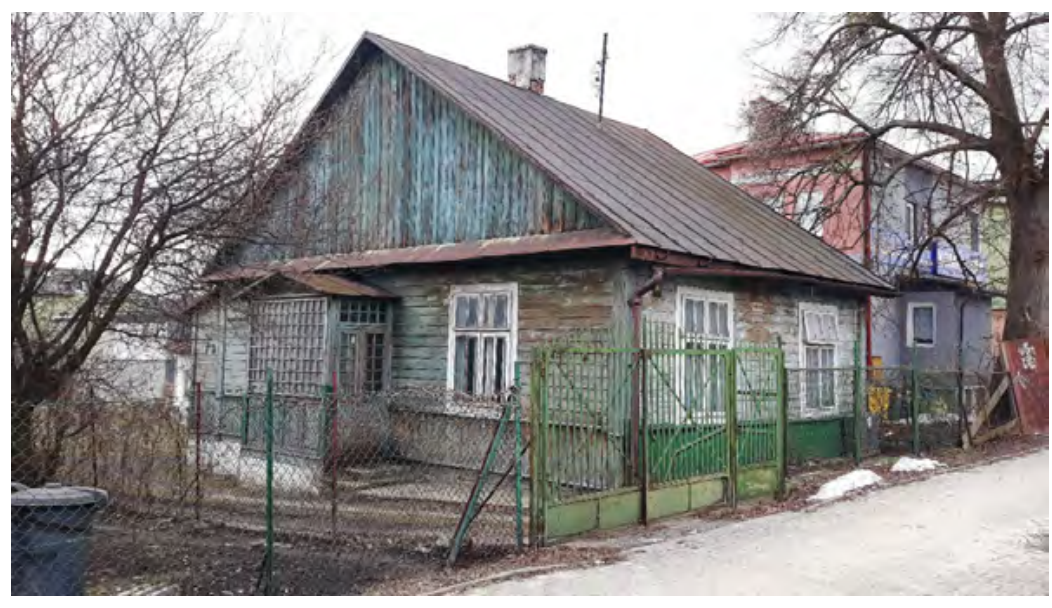

Fig. 7. Wooden residential building, Świętego Piątka 14

Source: author's photo

The National Heritage Board of Poland inaugurated a campaign "The landscape of my town" ("Krajobraz mojego miasta") dedicated to local governments, companies, institutions, town residents and local professionals. Their main goal is to draw attention to ubiquitous spatial chaos resulting from disorganized placement and outlook of advertisements and malfunctioning planning. One of the outcomes of that campaign is an informational film entitled "Beautiful, Polish, wooden" where groups of experts, the owners of wooden buildings and 
ardent fans of such type of architecture explain how to preserve wooden 'jewels' and save them from oblivion. The authors of the clip instruct on how to expose wooden architecture, plan suitable adaptation to new functions, support private owners in acquiring financial resources for the restoration and maintenance of wooden houses, educate younger generations on the value of wooden architecture to the landscape of a village, town, city, region and to save it for posterity. ${ }^{4}$

The National Heritage Board of Poland aspires to raise awareness among local government officials, owners of wooden houses, general public of preservation of wooden heritage in small towns and villages. In 2017, the National Heritage Board of Poland launched social spots starring very well-known actors from the Polish cult tv series "Ranczo" ('The Ranch') who encouraged viewers to introduce positive changes in urban and rural landscape such as planting Polish/ domestic species of trees, getting rid of, reducing, ordering a great number of outdoor billboards and advertisements as well as designing harmonious, stylistically aesthetical outer look of households and their surroundings (in the clip there is an example of placing typical, concrete fences around the plot that do not match the other elements of space arrangement such as, for example, garbage containers, finishing of the house).

Not infrequently, are wooden residential buildings underestimated and perceived as 'poor' houses. The street along which all the analyzed wooden buildings are placed used to be a part of an Old Lvovian Trail dating back to the end of the $16^{\text {th }}$ century. It would be beneficial to Zamość, the UNESCO heritage town, to improve a current image of Świętego Piątka Street by ordering or removing some, if not all, of the street advertisements

The National Heritage Board of Poland published a Report on the quality and condition of immobile monuments in Poland from 2017 where it was concluded that wooden building structures are under greatest threat of degradation. ${ }^{5}$ Owing to changing climate conditions and destruction of wooden substance as well as insufficient focus on wood conservation. Some objects of architectural and cultural value are not listed as registered monuments therefore, their fate might, in many cases, depend on private owners who are not knowledgeable in terms of cultural and aesthetical outlook of wooden buildings. Decisions regarding thermal insulation of such buildings have major consequences on a general landscape of public space, in that case, the street. In choosing an insulation technology, people are mainly driven by lower costs of materials and performance whereas the awareness of what impact such elevation might have on street users plays secondary, if any, importance. It is estimated that all the wooden buildings allocated at Świętego Piątka Street have a residential function so no other form of usage could be introduced. The Board ran some campaigns promoting alternative ways of using, especially abandoned, old, wooden buildings.

It could be observed that due to split ownership of one building, the two sides of a frontal elevation differ from one another, for example, one is covered with siding or plaster and the other keeps its original looks. Such incongruency adds to the overall stylistic, aesthetic chaos of the street and distorts the symmetry of a building.

Inadequate condition of old, wooden structures may result from ${ }^{6}$ :

- the usage of lower quality materials as a consequence of financially demanding conservation duties,

- insufficient care of owner in order to maintain proper technical quality of a building,

- the problem of possible fire destruction and the risk of theft,

- hectic, non-systematic refurbishment/partial,

a lack of thematic knowledge and proper conservationist supervision,

- refurbishment works entail too much intervention,

- specific works, such as thermal insulation, are sometimes irreversible and utterly alter the original outlook of a building,

- repair and maintenance works are executed by poorly qualified construction workers.

Very frequently are owners of old, wooden houses unaware of cultural context of a place lacking historical knowledge and basic rules of aesthetical space arrangement. They cater for their own interests and disregard the overall view of the space of the street. 
The problem is that some areas of the town are not treated and taken care of as whole entities which have their rules of management codified in municipal documents, such as, for example, city zoning plan or spatial development conditions and directions study.

Some wooden buildings located at Świętego Piątka St. are enlisted on the Municipal Record of Monuments. Moreover, local zoning plan imposes restrictions on development located at Świętego Piątka St. as it is a part of a zone " $\mathrm{B}$ " - area of conservation and heritage protection. They are the following:

- The obligation to receive from the voivodeship conservator of monuments rules of performance to build, modernize, refurbish, repair objects enlisted in the municipal record of monuments with the possibility of demanding to prepare historical, archeological, architectural or cultural landscape analysis (costs of the analysis covered by the investor)

- The obligation to receive proper decision from the conservator. The decision should check the introduction of the conservator's guidelines to the project.

The tools included in the zoning plans are insufficient.

Local government, public institutions and professionals should aspire to change local people's mindset about the value of the most immediate space they live in and make them aware of the fact that their wooden houses, their homes are very valuable elements of the town landscape and its history. One way of reviving the wooden landscape of Świętego Piątka Street could be the removal of chaotic, sometimes oversized outdoor advertisements and billboards.

\section{Bibliography}

[1] Zamościopedia - PRZEDMIEŚCIA, https://www.zamosciopedia.pl.

[2] Zamość i okolice 1936 - Mapa topograficzna, pas 46 - słup 36. Zbiór kartograficzny, Source: Courtest of the Zamość Archives, online archives: Kartografia - Zamość i okolice - $1936 \mathrm{r}$.

[3] Biblioteka Cyfrowa dLibra - Teka Zamojska, 1920, http://zamosc.pl.

[4] http://krajobrazmojegomiasta.pl/film-piekne-polskie-drewniane.

[5] Raport o stanie zachowania zabytków, Narodowy Instytut Dziedzictwa, RAPORT O STANIE ZACHOWANIA ZABYTKÓW NIERUCHOMYCH.pdf, https://nid.pl.

[6] Drewniany Skarb. Chroniąc dziedzictwo kreujemy przyszłość, Ośrodek Brama Grodzka Teatr NN.

[7] Teka Zamojska. Rok III. Nr 2 (Luty 1920); Biblioteka Cyfrowa dLibra - Teka Zamojska, 1920, http://zamosc.pl.

[8] Teka Zamojska. Rok III. Nr 3 (Marzec 1920); Biblioteka Cyfrowa dLibra - Teka Zamojska, 1920, http://zamosc.pl.

[9] https://www.zamosciopedia.pl; ulica Świętego Piątka; Przedmieścia. 